811.163.41'367.335.2

811.521'367.335.2

https://doi.org/10.18485/sj.2021.26.1.19

DIVNA D. GLUMAC

Univerzitet u Beogradu

Filološki fakultet
Оригинални научни рад

Примљен: 13. 10. 2020.

Прихваћен: 12. 1. 2021.

\title{
MODALNA ZNAČENJA JAPANSKE KAUZATIVNE REČENICE I NJIHOVA REALIZACIJA U SRPSKOM JEZIKU
}

Rad se bavi dvoagentivnom kauzativnom rečenicom u japanskom, koja osim značenja kauzativnosti, formalizovanog u pomoćnom glagolu saseru, obuhvata i značenje deontičke modalnosti, koja nema formalnog eksponenta na nivou rečenice. Cilj rada je da analizom prevodnih ekvivalenata ispita mogućnost da se, pored kauzativnih glagola u srpskom, u repertoar gramatičkih sredstava za prevođenje rečenica japanskog kauzativa uvrste i oblici kojim se iskazuje modalnost. Građu čine rečenice iz određenog broja dela japanskih pisaca i njihovih prevoda na srpski. Uočeno je da se u prevodu javljaju konstrukcije s modalnim glagolima morati, smeti, moći, kao i oblik futura prvog. Zaključuje se da se značenja japanskog kauzativa mogu preneti u srpski i formalnim sredstvima za iskazivanje modalnosti.

Ključne reči: kauzativ, japanski, srpski, modalnost, modalni glagoli, futur prvi, rečenična perspektiva.

\section{UVOD}

Dvoagentivna kauzativna rečenica u japanskom iskazuje radnju jednog lica istovremeno ističući odgovornost drugog. ${ }^{1}$ Kauzativna situacija obuhvata kauzirajuću i kauziranu situaciju čiji su nosioci lica. Radnja jednog zavisi od volje drugog.

*azuratdi@gmail.com

${ }^{1}$ Dvoagentivnu kauzativnu rečenicu smatramo tipičnom za kauzativ u japanskom. Osim odnosa između ljudi, kauzativ u japanskom jeziku opisuje i odnos između ljudi i pojava, stvari i pojava, odnos posesije i uzročno-posledični odnos. Detaljnije u: Glumac 2015. 
Stoga je neminovna modalna indikacija korelativnih situacija. Kauzator radnju inicira, omogućava ili onemogućava, dok kauzirani oseća da radnju može, mora, sme ili ne sme da izvrši. Značenje kauzativnosti je formalizovano pomoćnim glagolom saseru na nivou rečenice, dok je značenje modalnosti uslovljeno kontekstom i očitava se jedino na planu osećanja kauziranog, i zbog toga se često ispušta iz vida u učenju, prevođenju ili izučavanju japanske kauzativne rečenice.

Cilj ovog rada je da ukaže na prisustvo modalnog značenja u kauzativu u japanskom ${ }^{2} \mathrm{i}$ da ispita mogućnost da se pored kauzativnih glagola u srpskom u repertoar gramatičkih sredstava za prevođenje uvrste i oblici kojim se iskazuje modalnost. Razmatraju se konstrukcije s modalnim glagolima, kao i oblik futura prvog.

Primeri rečenica ekscerpirani su iz umetničke literature, jer takvi pružaju širi komunikativni kontekst, neophodan za identifikaciju posebnih kauzativnih kao i modalnih značenja. Obrađeno je 60 rečenica kauzativa prisile, 23 rečenice kauzativa dozvole, 54 rečenice kauzativa koristi, 5 rečenica kauzativa kontrapermisivnosti i 13 rečenica kauzativno-pasivne konstrukcije iz 9 književnih dela savremenih japanskih pisaca. Za određene tipove rečenica korpus nije nudio dovoljan broj primera, te su i zaključci o njima ograničeni. U radu je korišćena Hepburn transkripcija prilikom romanizacije japanskog teksta.

\section{TEORIJSKI OKVIR}

Prema Lajonsu (1977: 483, 489), kauzativna rečenica ima strukturu sa umetnutom rečenicom, koja je objekat apstraktnog glagola to cause (izazvati). Apstraktno značenje glagola izazvati sadržano je u značenjima glagola kao što su naterati, učiniti i dr. Umetnuta rečenica sa svojim subjektom-kauziranim iskazuje situaciju koja nastaje kao posledica kauzatorove aktivnosti. Šibatani (1976: 239-240) definiše kauzativnu situaciju kao makrosituaciju koju čine dva događaja, mikrosituacije, između kojih postoji odnos zavisnosti i kauzacije. Stoga u istraživanju polazimo od uzročno-posledične međuzavisnosti dveju radnji ili situacija.

Deontička modalnost se tiče logike obaveza i dozvola, nužnosti ili mogućnosti vršenja neke radnje od strane moralno odgovornog agensa-ispunitelja, a podrazumeva postojanje sile kao izvora obaveze ili zabrane koja se nalazi izvan agensa, poput drugog lica ili institucije koji za agensa predstavljaju autoritet (Lajons 1977: 823). Deontičku modalnost posmatramo kao spoljašnju motivacionu modalnost (Zvekić Dušanović 2010: 146). Izvor može biti i unutrašnji, kao unutrašnja prinuda (Lajons 1977: 824), a mogu biti i okolnosti, i tada se govori o dinamičkoj modalnosti (Palmer 1990: 9) ili o situacionoj modalnosti (Zvekić Dušanović 2008: 189). U kauzativnoj rečenici modalni izvor odgovara kauzatoru a ispunitelj kauziranom.

${ }^{2} \mathrm{O}$ različitim aspektima kauzativa u japanskom jeziku i problemima prevođenja na srpski u: Glumac 2016a, 2016b 2017a, 2017b, 2020. 
Poreklo deontičke modalnosti je u upotrebi jezika kao sredstva za izražavanje želje i nametanja svoje volje drugom (Lajons 1977: 826). Kauzator svoju želju saopštava indirektno, tvrdnjom, ili direktno, direktivom, kojim se nameće obaveza drugom agensu da propoziciju ostvari ili da se suzdrži od njenog ostvarivanja (Lajons 1977: 832).

\section{KAUZATIV U JAPANSKOM JEZIKU}

Kauzativni glagol se izvodi dodavanjem pomoćnog glagola saseru na osnovu punoznačnog glagola u aktivu, i odlikuje se dvojakom prirodom jer predstavlja zbir leksičkog značenja glagola aktiva i gramatičkog značenja kauzativa, od kojih su osnovna dva - značenje aktivnog prisiljavanja drugoga na radnju i značenje pasivnog davanja dozvole (Suzuki 1972: 286). Kauzativna rečenica u japanskom je proste strukture i ne sadrži umetnutu rečenicu. Sam kauzativni glagol svojim složenim oblikom obuhvata i kauzirajuću i kauziranu situaciju, a nosioci obe radnje su prisutni u rečenici - vršilac radnje kauzativa u ulozi subjekta i vršilac radnje aktiva u ulozi dopune. Teramura (1982: 289) objašnjava nastanak kauzativne rečenice uvođenjem novog lica, kauzatora, na mesto subjekta i promenom rečenične perspektive $u$ odnosu na rečenicu u aktivu.

Osnovna značenja kauzativa su prisila i dozvola (Kuroda 1965, Suzuki 1972, Šibatani 1973, Hajacu 2004). Radnja kauzatora nije eksplicitno iskazana već je izražena apstraktnim pomoćnim glagolom saseru. Kauzator čini nešto što za posledicu ima omogućavanje ili onemogućavanje kauziranom da izvrši radnju, te se navode i posebna značenja, kao što su uputstvo, dopuštanje, ostavljanje, nemešanje, samoprekor (Sunagava 1998); kauzativ činjenja koristi (Sato 1986); kauzativ zabrane ili kontrapermisivnosti (Hajacu 2004).

U japanskom jeziku kauzativ je i sociološka i psihološka kategorija. Između kauzatora i kauziranog često se uspostavlja odnos nadređeni-podređeni. Ističe se uloga kauzatora kao nadređenog i odgovornog za događaj u kojem sam nije učestvovao. Ta uloga uslovljena je socijalnim okvirom, porodičnim, pedagoškim, poslovnim i dr. Kauzativ izražava i subjektivni osećaj odgovornosti kauzatora zbog toga što je izazvao događaj ili osećaj krivice zbog toga što nije sprečio događaj. S obzirom na navedeno, obavezna je i modalna indikacija korelativnih situacija. U ovom radu bavićemo se onim dvoagentivnim kauzativnim rečenicama koje izražavaju situacije u kojima se radnja kauzatora nameće, omogućava ili sprečava aktivnim učešćem volje kauzatora, čime je omogućeno i prisustvo modalnog značenja, a to su kauzativ prisile, kauzativ dozvole, kauzativ koristi, kauzativ kontrapermisivnosti i kauzativno-pasivna rečenica. 


\section{MODALNOST I KAUZATIVNOST U JAPANSKOM JEZIKU}

Modalnost se u japanskom iskazuje flektivnim oblicima, kao što je nakereba narimasen, ali i sama upotreba kauzativa, implicira modalno značenje (deontička modalnost), jer se u kauzativnoj situaciji sučeljavaju volje dva učesnika. Isticanjem odgovornosti drugog za vršenje radnje i stavljajući ga na mesto subjekta, saopštava se da agens mora ili može da izvrši radnju po volji drugoga. Nosilac modalne kvalifikacije je lice koji saopštava o situaciji ili sam ispunitelj-kauzirani u ulozi govornika.

Podsticaj od strane kauzatora može biti: verbalni - u vidu zapovesti, uputstva, zabrane i sl.; psihološki - delovanjem na emocionalni stav drugog; fizički - pokret rukom i sl. (Sato 1986: 94). Konkretan oblik podsticaja nije iskazan već je implicitno sadržan u pomoćnom glagolu saseru, kao u primeru:

\begin{tabular}{|c|c|c|}
\hline $\begin{array}{l}\text { Oya-ga } \\
\text { roditelj }_{\text {мом }}\end{array}$ & $\begin{array}{l}\text { kodomo-wo } \\
\text { dete }_{\text {AKU }}\end{array}$ & $\begin{array}{l}\text { yūbinkyoku-ni } \\
\text { pošta }\end{array}$ \\
\hline
\end{tabular}

Roditelj šalje dete u poštu.

Podsticajni događaj je Oya-ga saseru (Roditelj čineći nešto izaziva), dok je rezultirajući Kodomo-ga yūbinkyoku-ni iku (Dete ide u poštu). Značenje spoljašnjeg deontičkog podsticaja moglo bi se konkretizovati i iskazati leksički, npr. aktivom glagola mērē suru (narediti), uz dopunsku rečenicu: Oya-ga kodomo-ni, yūbinkyoku-ni ikuyōni, mērē suru (Roditelj naređuje detetu da ide u poštu). Ovakav iskaz jasno saopštava o vrsti podsticaja, ali nema značenje faktivnosti, ${ }^{3}$ tj. značenje da je radnja dopunske rečenice i izvršena.

Situacija se može iskazati i iz ugla ispunitelja, modalnim oblikom: Kodomo-ga yübinkyoku-ni ik-anakereba naranai (Dete mora da ide u poštu). Tada se saopštava samo o stavu govornika prema radnji. Upotrebom kauzativne rečenice, međutim, saopštava se da agens mora ili može da izvrši radnju nametnutu ili odobrenu voljom drugog, pri čemu se podrazumeva da će radnju izvršiti jer značenje faktivnosti jeste odlika kauzativa u japanskom. Tako japanska kauzativna rečenica postaje zgusnut jezički izraz koji istovremeno obuhvata perspektivu i kauzatora i kauziranog, skrivajući konkretno (oblik podsticaja) i saopštavajući indirektno o apstraktnom (modalnom značenju).

\section{KAUZATIVNOST, REČENIČNA PERSPEKTIVA I MODALNOST U SRPSKOM}

Značenja dvoagentivnih kauzativa u srpskom izražavaju se kauzativnim glagolima, posebno tzv. ,prinudno-manipulativnim”, čija je glavna odlika delovanje na

\footnotetext{
${ }^{3}$ Termin prema Alanović 2012. U literaturi se koristi i termini „implikativnost” (Batistić 1978: 78).
} 
volju drugoga (Batistić 1978: 76). Manipulativno orijentisane kauzative Alanović (2010: 368; 370) definiše kao izazivanje radnje ili procesa u sferi drugog lica, što se ostvaruje kao obligatnost (prinuda), permisivnost (omogućavanje ili onemogućavanje) i stimulativnost (podstrekivanje). Prinuda, kao prototipično značenje, može da se zasniva na primeni sile od strane kauzatora, samo na proceni kauziranog o neminovnosti nastupanja posledica, i na drugim okolnostima, kao što je razlika u socijalnom statusu među učesnicima (Alanović 2010: 370). Tipični su glagoli prinuditi, naterati, primorati, poterati i dr. Permisivnost znači da kauzator svojom radnjom omogućava (protopermisivnost) ili onemogućava (kontrapermisivnost) kauziranom da obavi nameravanu ili aktivnost u kojoj je već angažovan (Alanović 2012: 460). Tipični su glagoli sa opštim značenjem omogućiti, onemogućiti, sprečiti, pomoći, odmoći, kao i glagoli direktivnog tipa dopustiti, zabraniti, narediti.

Modalnost se očitava u kauzirajućoj situaciji kao volja, želja ili namera u dejstvu kauzatora na kauziranog, dok se u kauziranoj situaciji ostvaruje kao deontičnost u osećanju kauziranog prema kauziranoj situaciji kao mogućoj, nemogućoj, potrebnoj ili nužnoj. Modalni glagoli u užem smislu su moći, trebati, morati, smeti, hteti (Piper/Klajn 2014: 284). Spoljašnja deontička modalnost u značenju podsticaja iskazuje se glagolima morati i trebati a u značenju mogućnosti iskazuje se glagolima moći i smeti (Zvekić Dušanović 2010: 146), najčešće uz dopunsku izričnu rečenicu $d a+$ prezent. Glagol morati izražava direktnu obligatornost, jaku neophodnost i značenje prinude, a njegovi semantički ekvivalenti su perifrastične konstrukcije biti primoran, biti prisiljen i dr.; glagol trebati označava slabiju nužnost, dok glagol moći ne mora da referiše o faktivnosti radnje iskazane punoznačnim glagolom (Piper 2005: 639, 640).

Iz značenja konstrukcije s glagolom narediti odnosno dozvoliti, kao reprezentima značenja spoljašnjeg deontičkog podsticaja odnosno mogućnosti, izvodi se značenje konstrukcije s modalnim glagolom, iskazane iz ugla tzv. ispunitelja propozicije, ,ja sam morao / mogao da + prezent" (jer mi je on naredio / dozvolio) (Zvekić Dušanović 2010: 155).

Situacija o kojoj referiše kauzativna rečenica u srpskom može se iskazati iz perspektive i jednog i drugog učesnika. Kauzatorovo dejstvo se izražava glagolom kauzativno-manipulativnog tipa a kauzirana radnja sentencijalnom ili nominalizovanom dopunom. Kauzirani je subjekat dopunske rečenice odnosno rekonstruisani subjekt u slučaju nominalizovane dopune (Batistić 1978: 76). Iskazana iz perspektive kauziranog kao objekta radnje, rečenica izražava delovanje lica podstaknutog na radnju (Alanović 2012: 453). Delovanje kauziranog iskazuje se aktivom glagola u osnovi ili konstrukcijom s modalnim glagolom (Udala se / Morala je da se uda zbog roditelja /jer su roditelji to zahtevali od nje). Kauzirajuća situacija se izražava imenicom kauzatora u predloško-padežnoj konstrukciji sa značenjem kriterijuma ili razloga, odnosno uzročnom rečenicom. 
U srpskom se i glagolska vremena koriste u značenju načina. Futur I se odlikuje transpozicijom primarno vremenskog u sekundarno modalno značenje (Kovačević 2017: 77-78; Tanasić 2005: 442-443). U modalnom značenju koristi se za iskazivanje stava govornika, uverenosti da će se ostvariti radnja iskazana značenjem glagola, zapovesti ili želje usmerene na radnju drugoga odnosno podsticaja drugome da izvrši ili ne izvrši radnju (Stanojčić/Popović 1995: 381; Stevanović 1974: 674; Tanasić 2005: 442). Taj podsticaj može pripadati tipu zapovesti, zabrane ili želje (Tanasić 2005: 443), čime se futur približava značenju imperativa.

\section{REALIZACIJE ZNAČENJA JAPANSKIH KAUZATIVNIH REČENICA U SRPSKOM}

Posmatraćemo semantičke specifičnosti i prevod na srpski rečenica japanskog kauzativa prisile, dozvole, zabrane i koristi, kao i kauzativno-pasivne rečenice, i mogućnost realizacije njihovih značenja gramatičkim sredstvima za iskazivanje modalnih značenja u srpskom.

\subsection{Kauzativ prisile}

U odnosu kauzator-kauzirani postoje socijalne razlike. Kauzator je po pravilu nadređen, što ga stavlja u poziciju da nametne svoju volju. Ređe, kauzator nema nameru niti je svestan svog dejstva prisile, ili je doveden u situaciju da mora da nametne vršenje radnje kauziranom. Tipične su situacije kada kauzirani nameće vršenje zadatka ili ispunjenje obaveze kauziranom po dužnosti, i tada je modalno značenje slabije izraženo. Kada kauzirani oseća nametnutu radnju kao smetnju ili štetu, rečenica iznosi i njegovo osećanje žrtve. Modalno značenje je tada naglašeno.

U prevodu kauzativa prisile najčešći oblik realizacije (30 od 60 primera) jeste konstrukcija s kauzativno-manipulativnim glagolima, kao što su primorati, narediti, naterati, prisiliti, tražiti, poslati, dati (zadatak, posao), reći, pozvati, iskazana iz perspektive kauzatora. Gotovo sve rečenice opisuju odnos nadređeni-podređeni ili potčinjeni, gde se nametanje radnje ne doživljava kao smetnja jer je ono očekivano za dati socijalni okvir. Ovakve rečenice daju neutralan ili objektivan opis, pripisujući odgovornost za događaj kauzatoru, koji je najčešće i tema pripovedanja. I kauzirani takvu situaciju prihvata kao prirodnu, te se ne može govoriti o izraženijem modalnom značenju.

1. Nakagorokara, naniarewa daitonosama-ga gyoi-ni shitagawaseyōto shite irassharunoda to iufu hyōban-ga tachihajimete. (Rashomon)

Ali se vremenom počelo govorkati kako je Veliki gospodar primorava da se pokori njegovim željama. (Akutagava 2011: 29) 
2. Nakamura-ni asu kippu-wo sochira-ni motte ikaseru. (Murakami 1988b: 37)

Poslaću Nakamuru da ti prekosutra donese karte. (Murakami 2013: 232)

Slično, iskazana iz perspektive kauzatora u prevodu, rečenica s prelaznim glagolom (5 primera) pokazuje nipodaštavanje volje kauziranog, čime se on izjednačava sa predmetom, i pravo kauzatora da nametne svoju volju:

3. Sokode Naigu-wa deshino hitori-wo zenno mukō-e suwarasete, meshi-wo kuu manaka, ita de, hana-wo mochiagete ite morau kotoni shita. (Hana) Zato je za vreme jela jednog od svojih učenika morao posaditi preko puta sebe, kako bi mu ovaj pridržavao nos štapom. (Akutagava 2002: 5)

Rečenica se alternativno može prevesti i iz perspektive kauziranog (16 primera), aktivom punoznačnog glagola ili upotrebom modalnog glagola morati da se naglasi saosećanje s kauziranim, kada se govori o nametanju volje koje prevazilazi uobičajeni okvir karakterističan za dati odnos, što se može iskazati leksički, izrazima kao što su wazawaza (i još, naročito), murini (na silu), ili sintaksički, umetnutom klauzom:

4. Heyade sakamori-wo shite, wazawaza sakana-wo koshiraesasetari nanika shite, ojōsan-ni mendō-wo misase [...]. (Gan)

[...] pravio bi terevenke u sobi i još je gnjavio gazdaricu da mu priprema meze i obilazi ga[...]. (Ogai 2015: 5) / dok je gazdarica morala još i da mu priprema meze i obilazi ga

5. Omawarisan-ga kuni-no nyōbōya kodomo-wo hoshiagete oite, ōkina kaowo shite sake-wo nonde, jōgo demonai jiisan-ni aite-wo sasete ita [...] (Gan)

Pozornik je ostavio ženu i decu da gladuju tamo u rodnom kraju, a ovde se ponašao k'o gazda i pio sake, dok mu je starac, koji nije bio sklon piću, pravio društvo. (Ogai 2015: 21) / morao da mu pravi društvo

Nasuprot tome, kada rečenica izražava prisilu u vidu zadatka, koji je deo uobičajenih dužnosti ili je i manji od toga, što se može istaći upotrebom izraza kao što je dake (samo), prisila se uopšte ne oseća, zbog čega je neadekvatna upotreba kauzativno-manipulativnih glagola. Rečenica se prevodi aktivom punoznačnog glagola iz perspektive kauziranog (3 primera):

6. Saisho hitohifutahino aida, jiisan-wa kireina ieni haiitta ureshisani, inakadeno jochūniwa, mizukumiya meshitakidake sasete, jibunde katatsuketari, sōji shitari shi[ta]. (Gan)

Prvih nekoliko dana starac je bio toliko srećan što se uselio u tako lepu kuću da ju je sam sređivao i čistio, dok mu je služavka-seljančica samo kuvala i donosila vodu[...]. (Ogai 2015: 38) 
Specifične su rečenice ( 1 primer) koje izražavaju nenamernu prisilu po tome što se kao prihvatljiv prevod uzima rečenica s modalnim glagolom iz perspektive kauziranog, dok bi se rečenica sa kauzativno-manipulativnim glagolom smatrala neodgovarajućom:

7. Watakushi-ga kuretekara, shokumotsunado-wo katte kaeruto, otōto-wa machiukete iite, watakushi-wo hitori-de kasegasetewa sumanai to mōshite orimashita. (Takasebune)

A kad bih se po pomrčini vraćao kući noseći nabavljene namirnice, mlađi brat bi me iščekivao i stalno mi se izvinjavao što [zbog njega] moram sam da zarađujem. (Ogai 2013: 22) / × što me je terao da zarađujem

Situacija se iskazuje iz perspektive kauziranog (2 primera) futurom u modalnoj upotrebi, sa značenjem zapovesti kada je kauzator govornik:

8. Yowayowashii karadani menjite, ni-wa karū shite toraseru. (Sansho) Nosićete [mi] lakši teret zato što ste slabašni. (Ogai 2012: 55)

Kad kauzator saopštava svoju želju trećem licu imperativom (2 primera), u srpskom se značenje posrednog prenošenja zapovesti na neprisutna lica izražava veznikom neka s glagolom u prezentu (Stevanović 1974: 704):

9. Ashita, mijikoro, Takashimano henmade, otokotachi-wo mukaini tsukawashi, soreni, kuraokiuma nihiki, hikasete maire. (Imogayu)

Pošaljite ljude da mu izađu u susret do Takašime oko deset časova sutra izjutra i neka povedu dva osedlana konja. (Akutagava 2004: 48)

Jedan je slučaj restrikcije u pogledu odabira perspektive iz koje će se kauzativna situacija iskazati u prevodu. Kada je kauzativni glagol deo složenog glagolskog predikata, poput konstrukcije „vezivni oblik + miru” (pokušati da), oba glagolska oblika pripisuju se istom rečeničnom argumentu, kauzatoru, te se u prevodu može javiti samo rečenica sa kauzatorom na mestu subjekta. Slično je i sa konstrukcijom „vezivni oblik + yō to suru” (truditi se, nastojati da):

10. Sokode uchini imai to sureba, shiite uchini isaseyō to suru. (Gan) Zato sam se trudio da ne budem kod kuće, ali je ona pokušavala da me silom zadrži. (Ogai 2015: 75)

\subsection{Kauzativ dozvole}

Inicijator radnje je kauzirani, dok kauzator kao nadređeni predstavlja davaoca dozvole. Česta je upotreba kauzativnog glagola u vezivnom obliku u konstrukciji s glagolom davanja, u značenju učtive molbe ili poniznog traženja dozvole.

Kada se o kauzatoru govori neutralno, kao o temi pripovedanja, prevodi se rečenicom s permisivnim glagolom dozvoliti i kauzatorom u ulozi subjekta (4 primera od 23): 
1. Sore-wo gosō surunowa, Kyōtomachi bugyōno haikani iru dōshinde, sono dōshin-wa zaininno shinruino nakade, omodatta hitori-wo, Ōsaka made dōsen saseru koto-wo yurusu kanreide atta. (Takasebune)

Pratio ga je redar koji je bio u službi upravitelja grada Kjota, a bilo je uobičajeno da taj redar dozvoli jednom od najbližih osuđenikovih srodnika da bude s njim u čamcu do Osake. (Ogai 2013: 23)

$\mathrm{Na}$ isti način se prevodi i kada se ističe volja ili odgovornost kauzatora (4 primera), ili samoprekor kada je kauzator prvo lice (3 primera):

2. Unumade shinasete naru monoka. (Sansho) Misliš da ću dozvoliti da mi umre još jedna? (Ogai 2012: 53)

Kada je kauzator prvo lice a kauzirani drugo, značenje dozvole drugom licu može se alternativno iskazati imperativom punoznačnog glagola ili konstrukcijom s modalnim glagolom moći (1 primer):

3. Hōbi-niwa nozomi-no mono-wo toraseruzo. (Rashomon)

Kao nagradu dozvoljavam ti da uzmeš / uzmi / možeš da uzmeš što god želiš. (prevod autora)

Najveći broj primera (12) jesu konstrukcije kauzativnog glagola sa glagolom davanja kojom kauzirani izražava učtivu molbu ili ponizno traži dozvolu. Rečenice s glagolom dozvoliti ili dati u imperativu ili u obliku futura sa modalnim značenjem želje iz ugla kauzatora kao modalnog izvora u prevodu se mogu alternativno izraziti i konstrukcijom s modalnim glagolima moći ili smeti, iz ugla kauziranog-ispunitelja:

4. Sono kawari denwa-wo kakasete. (Murakami 2001a: 394) Zauzvrat, dozvolićete mi da telefoniram. (Murakami 2013: 187)

5. Sakki no tsuzuki-wo mōsukoshi iwasete kudasaimasen ka. (Soseki 1965: 388)

Mogu li / Smem li / Dozvolite mi da kažem ono što sam malopre započeo? (Soseki 2003: 58)

6. Sō ieba, shiteki kōen-roku mitaina monono temochimo arundakedo, moshi supēsuga attara rensai sasete kuremasenka? (Murakami 2015: 310)

Nego, imam kod sebe nešto kao privatnu skriptu predavanja, pa ako bude bilo prostora, da li bi možda to moglo da se objavi u vidu serijala? (Murakami 2019: 227)

\subsection{Kauzativ kontrapermisivnosti}

Opšte značenje kontrapermisivnosti ostvaruje se kao zabrana, sprečavanje ili nepuštanje. Inicijator je kauzirani, dok kauzator svesno i voljno onemogućava izvršenje radnje. Kauzativni glagol je u odričnom obliku, sasenai. Obrađeni korpus nije pružio dovoljno primera (ukupno 5). 
Opšte značenje kontrapermisivnosti prevodi se iz perspektive s kauzatora glagolom dozvoliti ili dati u odričnom obliku, koji je u pogledu nametanja volje neutralniji od kontrapermisivnog glagola zabraniti:

1. Samushiikara motto ite kure to iunoga omona riyū deattaga, hahaya watashi-ga, tabetaidake mono-wo tabesasenai to iu fuhē-wo uttaerunomo, sono mokutekino hitotsu deattarashii. (Soseki 1965: 429)

Glavni razlog tome je bila očeva usamljenost, ali i želja da se nekome požali na majku i mene koji mu nismo dozvoljavali da jede koliko je hteo. (Soseki 2003: 121) /

2. Tabibito-ni ashi-wo todomesasemai to shite, ikikureta mono-wo rotō-ni mayowaseru yōna okite-wo, kokushu-wa naze sadameta mono ka. (Sansho) Zašto li je gospodar izdao naredbu da se putnici koje mrak uhvati na putu ne smeju primiti na prenoćište? (Ogai 2012: 48) / zabranio da se primaju

Kada je izvor zabrane govornik, značenje kontrapermisivnosti može se alternativno iskazati i iz ugla kauziranog, odričnim oblikom punoznačnog glagola u futuru s modalnim značenjem visokog stepena uverenosti govornika da će se ostvariti radnja iskazana značenjem glagola:

3. Darenimo yokēna kuchi-wa dasasenai. (Murakami 2001b: 189)

Niko meni neće naređivati. (Murakami 2013: 320) / ne dam / ne dozvoljavam nikome da mi naređuje.

\subsection{Kauzativ koristi}

Kauzator omogućuje kauziranom da izvrši radnju koja je po njega, kauziranog, povoljna. Česta je upotreba kauzativnog glagola u konstrukciji „,-sasete + glagol davanja / primanja", koja izražava davanje ili primanje koristi. Iako akcenat nije na razlici, kauzator je obično nadređen po društvenom statusu ili po sposobnostima, i u poziciji je da učini korist.

Značenje činjenja koristi iz perspektive kauzatora u prevodu se iskazuje konstrukcijom sa protopermisivnim i stimulativnim kauzativnim glagolima (22 primera od 50), kao što su dozvoliti, olakšati, omogućiti, pomoći, nuditi, dati, pobrinuti se, postarati se, truditi se i dr, uz sentencijalnu ili nominalizovanu dopunu kojom se iskazuje radnja kauziranog. Alternativno, moguć je i prevod rečenice iz perspektive kauziranog aktivom punoznačnog glagola ili konstrukcijom s modalnim glagolom moći, s tim što se tada kauzator kao spoljašnji modalni izvor mora izraziti, predloško-padežnim adverbijalom ili glagolskim prilogom ,zahvaljujući + dativ":

1. [...] watakushiwa tomokakumo, kodomorani okayudemo tabesasete, yaneno shitani yasumaseru kotoga dekimashitara, sonogo onwa nochino yomademo wasuremasumai. (Sansho) 
[...] ako biste vi mogli dati tople kaše, barem deci ako ne i meni, i dozvoliti / omogućiti nam da se smestimo pod vašim krovom, nikada vam to ne bismo zaboravili. / ako bismo se kod vas mogli smestiti i pojesti tople kaše (prev.autora)

2. Moshi watashidakede ryokō shite itara mazu keiken shinakattayōna kotowo iroiro keiken sasete kureta. (Murakami 2001: 144)

Ja sam zahvaljujući njoj iskusila / mogla da iskusim mnoge stvari koje sigurno ne bih da sam sama putovala. (Murakami 2004: 101) / ona mi je omogućila da iskusim

Veliki je udeo (13 od 50) primera sa kauzativom glagola taberu (jesti) i nomu (piti). Kao prevodni ekvivalenti, sa kauzatorom na mestu subjekta, javljaju se glagoli dati, hraniti, služiti, nuditi, prirediti (večeru i dr.) ili konstrukcija dati da jede / pije. Kao varijanta, i ovde je moguć prevod rečenice iz perspektive kauziranog aktivom punoznačnog glagola ili konstrukcijom s modalnim glagolom moći:

3. Sore-ga orōni haiittekarawa, iji-wo sezuni tabesasete itadakimasu. (Takasebune)

A od kad su me stavili u zatvor, hrane me a ne moram ništa da radim. (Ogai 2013: 22) / mogu da jedem

4. Otokodomo, shiyatsunimo, mono-wo kuwasete tsukawase. (Shiro)

Momci, dajte i njoj da se najede. (Akutagava 2004: 55) / neka se i ona najede

5. Soshite umai mono-wo tabesaseru mise-wo sagashite mawaru shigotono hanashi-wo shita. (Murakami 2001a: 198)

Onda sam joj govorio o svom poslu traženja mesta koja nude dobru hranu. (Murakami 2013: 122) / u kojima može dobro da se pojede

Ostale rečenice iskazuju brigu o nemoćnom, nezbrinutom licu, detetu i sl. Kauzativ glagola koji iskazuju brigu o deci (8 primera), prevodi se prelaznim glagolima kao što su nahraniti, staviti na spavanje, pokriti, okupati. Po pravilu, ovakve kauzativne rečenice ne obuhvataju modalno značenje, te je i mogućnost prevoda modalnim glagolom isključena:

6. Kutabireta kodomora-wo sakie nesasete, haha-wa yadono shujinni minoueno ōyoso-wo hanashita. (Sansho)

Nakon što je prvo iznurenu decu stavila na spavanje, majka je domaćinu ispričala ponešto o njima. (Ogai 2012: 50)

\subsection{Kauzativno-pasivna rečenica}

Dodavanjem pomoćnog pasivnog glagola rareru na osnovu kauzativnog glagola sase-, čime nastaje složeni pomoćni glagol saserareru (kraće: sareru), koji se dodaje na osnovu punoznačnog glagola. On obuhvata značenja i kauzativa i pasiva. 
Kauzativ se koristi samo u značenju prisile, dok pasiv, osim trpljenja radnje, izražava i trpljenje smetnje ili štete usled odigrane radnje. Kauzativno-pasivna konstrukcija iskazana je s tačke gledišta kauziranog, i kao izraz modalnosti naglašava značenje da on vrši radnju protiv svoje volje jer je na to prisiljen, istovremeno ističući njegovo osećanje smetnje. Kauzirani na mestu subjekta je istovremeno i primalac podsticaja i vršilac radnje i pacijens.

U ulozi subjekta je najčešće govornik ili treće lice kojem govornik pripisuje osećanja. Kauzator je ređe iskazan jer je akcenat na osećanju kauziranog. Stoga je u obrađenom korpusu u prevodu svih 13 primera situacija po pravilu iskazana iz ugla kauziranog, konstrukcijom s modalnim glagolom morati ili perifrastičnom konstrukcijom s njegovim semantičkim ekvivalentom, prinudno-manipulativnim glagolom prisiliti ili primorati u pasivu:

1. Are-wo kikasareteru to, watashi, atama-ga itaku natte kuru noyo. (Murakami 2001b: 71)

Mene zaboli glava kad moram ovo da slušam. (Murakami 2013: 251)

2. Kudaranai supiichi-wo kikasarete, tsukurisokone-no renga mitaina kēkiwo miyage-ni motasareru. (Murakami 2001b: 189)

Pa da moram da slušam bezvezne zdravice i da u znak zahvalnosti dobijem tortu nalik na okrnjenu ciglu. (Murakami 2013: 319)

3. Watashi-wa soko-de biiruno awa-no yōna kare-no kien-wo kikasareta. (Soseki 1965: 415)

Tu sam bio prisiljen da slušam njegovo brbljanje, zapenjeno poput pivske pene. (Soseki 2003: 98)

4. Imamade nanbenmo sore-wo kikasareta watashito ani-wa, itsumotowa marude chigatta kibunde, haha-no kotoba-wo chichi-no kinen no yōni mimi-e ukeireta. (Soseki 1965: 439-440)

Iako smo brat i ja tu priču do tada čuli bezbroj puta, ovoga puta smo je slušali na sasvim drugi način. (Soseki 2003: 135)

5. Watashi-wa karerakara uketa kutsujokuto songai-wo kokyōno tokikara kyōmade seowasarete iru. Osoraku shinu made seowasaretōshi deshō. (Soseki 1965: 407)

Od detinjstva pa sve do danas ja nosim breme uvreda i rana od njih zadobijenih. I verovatno ću morati da ga nosim sve do svoje smrti. (Soseki 2003: 86)

Govornikov stav prema radnji može biti iskazan i drugim gramatičkim sredstvima s negativnom konotacijom - klauzom, atama-ga itaku naru (mene zaboli glava) ili leksički: atributivom uz imenicu objekta, kudaranai supiichi (bezvezne zdravice); imenicom u ulozi objekta, kien (brbljanje), kutsujoku to songai (breme uvreda i rana); priloškom odredbom, nanpenmo (bezbroj puta); glagolom u osno- 
vi, seou (nositi teret na leđima). Tada se može prevesti i aktivom, iz perspektive kauziranog.

\section{ZAKLJUČAK}

Ukoliko se u prevodu iskaže iz perspektive kauzatora po ugledu na japansku rečenicu, kauzativ se realizuje prinudnim, permisivnim ili stimulativnim glagolima kauzativno-manipulativnog tipa, uz dopunsku rečenicu s punoznačnim glagolom koji izražava radnju kauziranog. Odgovornost za događaj se pripisuje kauzatoru, koji je najčešće i tema pripovedanja, a u pogledu modalnog značenja, rečenice su neutralne.

Da bi se u prevodu izrazila značenja deontičke modalnosti, kauzirana situacija se iskazuje iz ugla kauziranog, konstrukcijom s modalnim glagolima morati, moći i smeti uz dopunsku rečenicu, ili upotrebom futura I i imperativa za drugo ili treće lice punoznačnog glagola kojim se izriče radnja kauziranog.

Glagol morati koristi se u prevodu kauzativa prisile kada se govori o nametanju volje koje prevazilazi uobičajeni okvir karakterističan za dati odnos, kao i u prevodu kauzativno-pasivne rečenice kako bi se izrazilo osećanje smetnje ili žrtve kauziranog usled toga što je prisiljen da izvrši radnju protiv svoje volje.

Glagol moći koristi se u prevodu kauzativa dozvole, posebno kada je kauzator prvo lice a kauzirani drugo, zatim u prevođenju konstrukcije kauzativnog glagola sa glagolom davanja kojom kauzirani izražava učtivu molbu ili ponizno traži dozvolu, gde se alternativno javlja i glagol smeti, kao i u prevodu kauzativa koristi, ali se tada kauzator kao spoljašnji modalni izvor mora izraziti, i to predloško-padežnim adverbijalom ili glagolskim prilogom ,zahvaljujući + dativ”.

Restrikcije u upotrebi modalnih glagola postoje u prevodu kauzativa prisile kod odnosa nadređeni-podređeni gde se nametanje radnje ne doživljava kao smetnja jer je ono očekivano za dati socijalni okvir, kada rečenica izražava prisilu u vidu zadatka ili uobičajenih dužnosti, zatim kada je kauzativni glagol deo složenog glagolskog predikata, kao i u prevodu rečenica koje iskazuju brigu o nemoćnom ili nezbrinutom licu, detetu i sl. jer one ne obuhvataju modalno značenje.

Futur I se koristi u prevodu kauzativa prisile u modalnoj upotrebi sa značenjem zapovesti kada je kauzator govornik. U odričnom obliku koristi se u prevodu kauzativa kontrapermisivnosti kada je izvor zabrane govornik, u značenju visokog stepena uverenosti govornika da se neće ostvariti radnja punoznačnog glagola.

Imperativom punoznačnog glagola iskazuje se u prevodu značenje kauzativa prisile ili dozvole kada kauzator-govornik saopštava svoju želju drugom licu. Za posredno prenošenje zapovesti na neprisutna lica, u prevodu se koristi veznik neka s glagolom u prezentu. 


\section{LITERATURA}

Alanović 2010: M. Alanović, Tipološke odlike i principi klasifikacije leksičko-gramatičkih kauzativa, Naučni sastanak slavista u Vukove dane, 39/1, 361-375.

Alanović 2012: M. Alanović, Kauzativno-manipulativni glagoli: derivaciono motivisane semantičke i argumentne varijacije, u: R. Dragićević (gl. ur.): Tvorba reči i njeni resursi u slovenskim jezicima: zbornik radova sa četrnaeste međunarodne naučne konferencije Komisije za tvorbu reči pri Međunarodnom komitetu slavista, 453-467.

Batistić 1978: T. Batistić, O nekim aspektima analize kauzativnih glagola, Južnoslovenski filolog, XXXIV, 59-86.

Glumac 2015: D. Glumac, Kauzativ i glagolski rod u japanskom jeziku u poređenju sa srpskim jezikom, [doktorska disertacija], Beograd: Filološki fakultet.

Glumac 2016a: D. Glumac, Realizacije japanske kauzativne konstrukcije u srpskom jeziku, u: A. Mitrović, Lj. Marković (ur.), Orijentalistika juče - danas - sutra: međunarodna naučna konferencija. Zbornik rezimea, Beograd: Filološki fakultet, 142-143.

Glumac 2016b: D. Glumac, Tipovi japanske kauzativne rečenice i njihovi prevodni ekvivalenti u srpskom jeziku, u: A. Mitrović (prir.), Orijentalističko znamenje - sećanje na Mariju Đukanović, Beograd: Filološki fakultet, 287-297.

Glumac 2017a: D. Glumac, Značenje kauzativa u japanskom jeziku i neki problemi u prevođenju na srpski, Anali Filološkog fakulteta, XXIX/2, 83-99.

Glumac 2017b: D. Glumac, Prevođenje japanskog kauzativa posesije sa živim subjektom na srpski jezik, Primenjena lingvistika, 18, 7-19.

Glumac 2020: D. Glumac, Kauzativ glagola emocija, percepcije i kognicije u japanskom jeziku, Komunikacija i kultura online, 11, 100-123.

Hajacu 2004: E. Hayatsu, Shieki hyōgen, Asakuranihongo kōza 6: Bumpō II, Asakurashoten, 128-150.

Kovačević 2017: M. Kovačević, Modalna upotreba vremenskih glagolskih oblika, u: Jezik, književnost, vreme: jezička istraživanja, Zbornik radova, Niš: Univerzitet u Nišu, Filološki fakultet, 77-89.

Kuroda 1965: S. Y. Kuroda, Generative Grammatical Studies in the Japanese Languages, Ph.D. Dissertation, MIT.

Lajons 1977: J. Lyons, Semantics, Vol. 2, Cambridge University Press. 
Palmer 1990: F. R. Palmer, Modality and the English Modals, London: Longman.

Piper i dr. 2005: P. Piper i dr., Sintaksa savremenoga srpskog jezika. Prosta rečenica, Beograd: Institut za srpski jezik SANU, Beogradska knjiga; Novi Sad: Matica srpska.

Piper/Klajn 2014: P. Piper, I. Klajn, Normativna gramatika srpskog jezika, Novi Sad: Matica srpska.

Sato 1986: S. Satō, Shiekikōzō no bun, Kotobano kagaku 1, Tōkyō: Gengogaku kenkyūkai.

Stanojčić/Popović ${ }^{4}$ 1995: Ž. Stanojčić, Lj. Popović, Gramatika srpskoga jezika, Beograd: Zavod za udžbenike i nastavna sredstva.

Stevanović 1974: M. Stevanović, Savremeni srpskohrvatski jezik: (gramatički sistemi i književnojezička norma), II, Sintaksa, Beograd: Naučno delo.

Sunagava 1998: Y. Sunagawa i dr., Kyōshi to gakushūsha no tame no nihongo bunkē jiten, Tōkyō: Kuroshio.

Suzuki 1972: S. Suzuki, Nihongobunpō - kētairon, Kyōiku bunko 3, Tōkyō: Mugishobō.

Šibatani 1973: M. Shibatani, Semantics of Japanese Causitivization, Foundations of Languages 9.

Šibatani 1976: M. Shibatani, Causativisation, u: M. Shibatani (ur.), Syntax and Semantics 5, New York: Academic Press, 239-294.

Tanasić 2005: S. Tanasić, Sintaksa glagolskih oblika, u: P. Piper i dr., Sintaksa savremenoga srpskogjezika. Prosta rečenica, Beograd: Institut za srpski jezik SANU, Beogradska knjiga; Novi Sad: Matica srpska, 345-476.

Teramura 1982: H. Teramura, Nihongo no shintakusu to imi I, Tōkyō: Kuroshio shuppan.

Zvekić Dušanović 2008: D. Zvekić-Dušanović, O srpskim konstrukcijama sa modalnim značenjem 'unutrašnjeg podsticaja' i njihovim mađarskim ekvivalentima, Zbornik Matice srpske za filologiju i lingvistiku, 51/1-2, 189-204.

Zvekić Dušanović 2010: D. Zvekić-Dušanović, O predikatima tipa treba hteti, treba smeti..., Zbornik Matice srpske za filologiju i lingvistiku, 53/1, 145-162. 


\section{Izvori}

Akutagava 2004: R. Akutagava, Beli, Sombor: Publikum.

Akutagava 2011: R. Akutagava, Pakao i druge priče, Beograd: Tanesi.

Imogayu; Rashomon; Sansho; Shiro; Takasebune: https://www.aozora.gr.jp, 24.07.2014.

Gan: https://www.aozora.gr.jp, 20.09.2020.

Murakami 2001: H. Murakami, Supūtonikuno koibito, Tōkyō: Kōdansha.

Murakami 2001a: H. Murakami, Dansu Dansu Dansu I, Tōkyō: Kōdansha.

Murakami 2001b: H. Murakami, Dansu Dansu Dansu II, Tōkyō: Kōdansha.

Murakami 2004: H. Murakami, Sputnik ljubav, Beograd: Geopoetika.

Murakami 2013: H. Murakami, Igraj igraj igraj, Beograd: Geopoetika.

Murakami 2015: H. Murakami, Shokugyō to shite no shōsetsuka, Tōkyō: Suicchi Paburisshingu.

Murakami 2019: H. Murakami, Pisac kao profesija, Beograd: Geopoetika.

Ogai 2012: M. Ogai, Gazda Sanšo, Letopis Matice srpske, 48, 115/1, Novi Sad: Matica srpska.

Ogai 2013: M. Ogai, Takasebune, Srpski književni list, br. 3/108, 2013, 22-23.

Ogai 2015: M. Ogai, Divlja guska, Beograd: Tanesi.

\section{MODAL MEANINGS OF JAPANESE CAUSATIVE SENTENCE AND THEIR REALIZATIONS IN SERBIAN}

\section{Summary}

The paper deals with the two-agent causative sentences in Japanese, which express the action of one person while emphasizing the responsibility of another. Since the causative situation involves two situations, the causing and the caused one, confronting the volition of the two actors involved, the modal indication of the correlative situations is inevitable. While the causative meaning is formalized in the auxiliary verb saseru, the meaning of deontic modality has no formal exponent on the sentence level, and is often overlooked in learning, translating or studying.

The aim of the paper is to point out the presence of modal meanings in the Japanese causative sentences, and to examine the possibility of including the forms that express modality in Serbian in the repertoire of grammatical means of translating Japanese causative sentence, in addition to causative verbs. Constructions with modal verbs and the form of the future tense are considered. Emphasis is placed on semantic analysis. The material is 
extracted from a number of literary works of contemporary Japanese writers and their literary translations into Serbian.

Key words: causative sentence, Japanese, Serbian, modality, modal verbs, futur tense, sentence perspective.

Divna D. Glumac 